\title{
COMBINED EFFECT OF TILLAGE SYSTEMS, SOWING METHODS AND WEED CONTROL TREATMENTS ON WHEAT YIELD AND ASSOCIATED WEEDS
}

\author{
Abd El-Samei, F.S.; H. Mahfouz; Ekram A. Megawer and M.E. Rady \\ Agron. Dept. , Fac. Agric. , Fayoum University
}

ABSTRACT

Two filed experiments were conducted at the Experimental Farm of Faculty of Agriculture, Fayoum University in the two successive growing seasons 2006/2007 and 2007/2008 .The principal aim was to investigate the effect of tillage system, sowing methods, weed control treatments and their interactions on growth, yield, yield components and grain protein content. The experiments were laid-out in a Split-Split Plot arranged in Randomize Complete Block design with four replications. The plot area was $10.5 \mathrm{~m}^{2}$. The wheat variety used was Sakha94. Results generally showed that the major weeds species associated with wheat crop were mostly broadleaved weeds. The lowest weights in fresh and dry broad leaved weeds was obtained with tillage system $\left(\mathrm{T}_{2}\right)$ compared with ordinary tillage $\left(T_{1}\right)$ in both seasons, and significantly increased plant height, number of spikes $/ \mathrm{m}^{2}$, number of grains /spike, grain weight $(\mathrm{g})$ /spike, , total protein percentage, and grain yield (ton/fed). Drilling method decreased the fresh and dry weight of weeds compared with broadcasting method and increased plant height, flag leaf area, number of grains/spike, grain weight/spike seed index (g), , harvest index (\%), and grain yield. On the other hand broadcasting method increased only number of tillers/plant, in second season and straw yield ( ton/fed)in both seasons.

All chemical weed control treatments decreased fresh and dry weights of broad-leaved weeds compared with unweeded. The highest reduction in broad-leaved weeds was achieved with Tribenuron-methyl $(95 \%)$ along with hand weeding (70\%). Also these treatments had significant effects on yield and yield components as well as, the total protein percentage in grains. Tribenuron-methyl treatment exhibited the highest grain yield $(2.62$ and $2.72 \mathrm{t} / \mathrm{fed}$.) followed by hand weeding treatment (2.08 and $2.0 \mathrm{t} / \mathrm{fed}$ ) in first and second season, respectively.

Interaction effect between tillage systems $(\mathrm{T})$ and weed control (WC) was significant on plant height at harvest, flag leaf area, and harvest index. While the interaction between sowing methods (SM) and weed control (WC) was significant on number of tillers/plant, number of spikes/plant, number of grains /spike.

Key words: Wheat, Tillage system, Sowing methods, Weed control, Growth, Yield and quality

\section{INTRODUCTION}

Wheat (Triticum aestivum L.) is the most important edible crop in Egypt. But unfortunately the local production of grain wheat is not enough to achieve self-sufficiency due to high increasing rate of population combined with high consumption per capita in addition to the presence of some

Fayoum J. Agric. Res. \& Dev., Vol.23, No.1,(B). January, 2009 
production constraints. Weeds associated wheat are among the great constraints causing yield losses due to their severe competition with crop plants for nutrient, water, light and spacing. Several authors showed that wheat yield losses were in the ranges of 4-33 (Madeira et al, 1984), 40- 49 (Alam et al, 1994), 40 - 43 (El-Bowab and Kholousy, 2003) and 24- 40\% (Oad et al, 2007) depending upon the intensity and species of weeds.

Weed control is one of essential cultural practices for raising wheat yield and improving its quality. Getting rid of weed could be achieved through direct methods such as herbicides application or manual weeding as well as indirect methods such as land preparation and sowing method. However, manual removal of weeds is very expensive, time consuming and may be injured the crop plant and influenced its growth. Herbicides application not only control the weeds effectively but also reduce the cultivation cost.

Application of Isoproturon (50 or $75 \%$ WP) was the best control treatment and gave the maximum wheat grain yield Kushwaha and Singh, 2000; Marwat et al, 2005 and Raghuvir et al, 2006). Isoproturon also but combined with 2,4-D (Prasad $\boldsymbol{e t} \boldsymbol{a l}, \mathbf{2 0 0 5}$ ), with pendimethalin (Saini $\boldsymbol{e t}$ al, 1998)was the best weed control and resulted in improved wheat yield and its components. However, hand weeding resulted in lighter weed intensity and dry weight than those of Isoproturon as well as those of pendimethalin (Singh et al, 2000) and than those of Sulfuron herbicide treatment (Pandey and Kumar,2005).

Satao et al (1993) reported that all weed control treatments in wheat outyielded that of unweeded one, and hand weeding twice produced the greatest yield where it eliminated $69-98 \%$ of weeds, followed by Isoproturon + hand weeding once that eliminated $66-80 \%$ of weeds. ElKholi and Metwally (2001) and Sujoy et al (2006) revealed that hand weeding once or twice significantly reduced fresh weight of annual weeds. On the other hand, Zand et al (2007) suggested that hand weeding might not aways be considered as the best weeding control method in wheat because of possible damages of hand weed on wheat crop.

Several wheat investigators found that drilling sowing method outyielded broadcasting one and more effective for weed control ( Abd ElSamei, 2001; Galal, 2003 as well as Pandey and Kumar, 2005). Kassahun and Suwaketnikom (2005) showed that weed density increased in no tillage compared with conventional tillage or mouldboard plough which was the best weeds control and produced the highest grain yield. Whereas, Mishra et al (2005) obtained the greatest wheat grain yield (4.76 t/ha) from zero tillage. Pandey et al (2006) obtained the highest grain and straw yields with minimum tillage.

In integrated weed management approach, two or more methods should be selected to overcome the weed problem. Zimdahl (1993) indicated that this approach will consider culture method such as seeding rate and method, hand preparation and use of competitive cultivars in addition to mechanical and chemical methods. Bhat and Mahal(2006) found that integrated weed control (Clodinafob, $0.045 \mathrm{~kg} / \mathrm{ha}$, + hand / mechanical weeding) proved significantly superior to hand/ mechanical weeding and weedy control.

Fayoum J. Agric. Res. \& Dev., Vol.23, No.1,(B). January, 2009 
Therefore, the main target of this investigation is to study the efficiency of some tillage systems, sowing methods and weed control treatments on the growth and yield of wheat and its associated weed.

\section{MATERIALS AND METHODS}

Two field experiments were conducted during 2006/2007 and 2007/2008 seasons at the Experimental Farm of the Faculty of Agriculture, Fayoum University. The experiments were laid-out in a Split-Split Plot arrangement in randomized complete block design with four replicates. The tested treatments were : two tillage systems, i.e., normal tillage only $\left(\mathrm{T}_{1}\right)$ and normal tillage followed by false irrigation $\left(\mathrm{T}_{2}\right)$ arranged in the main plots, two sowing methods, i.e., seed drilling method in rows $15 \mathrm{~cm}$ apart $\left(\mathrm{SM}_{1}\right)$ and broadcasting method $\left(\mathrm{SM}_{2}\right)$ allocated in sub-plots; and four weed control treatments laid out in sub-sub plots. These weed control treatments were: Tribenuron-methyl "Granstar 75\%WP", at the rate of $8 \mathrm{~g} / \mathrm{fed}$. $\left(\mathrm{WC}_{1}\right)$; Isoproturon $(83 \% \mathrm{WP})$, (Isogard) at the rate of $900 \mathrm{~g} / \mathrm{fed}$. $\left(\mathrm{WC}_{2}\right)$; hand weeding twice before $1^{\text {st }}$ and $2^{\text {nd }}$ irrigation $\left(\mathrm{WC}_{3}\right)$ and unweeded, "control" $\left(\mathrm{WC}_{4}\right)$. The two herbicides were applied at 2-4 leaf stage as post emergence, by using knapsack sprayer with volume 2001/ feddan.

The dominant weed in wheat plots during the two seasons were : Beta vulgaris L., Rumex dentatus L., Trifolium resupinatum L., and Medicago hispida L. Weeds were hand pulled at 90 days after sowing from one square meter area in each plot, then classified into broad and narrow leaved weeds. After drying at $70 \% \mathrm{C}^{\circ}$ for 48 hours, dry weight was recorded.

Growth parameters of wheat were measured on five plants randomly chosen from each plot at 105 days from sowing to determine the average of plant height $(\mathrm{cm})$, number of tillers/plant, number of spikes/plant, and flag leaf area $\left(\mathrm{cm}^{2}\right)$. The latest trait (FLA) was recorded after heading by taking a sample of five leaves per entry in each replication and calculated from the product of leaf length and maximum breath* 0.75 , according to Richards (1983).

At harvest time, five wheat plants were randomly chosen from each plot to determine; plant height $(\mathrm{cm})$, number of grains/spike, grain weight/spike and seed index (1000grain weight). Also at harvest, one square meter in each plot was randomly selected to assess number of spikes $/ \mathrm{m}^{2}$, grain yield, straw yield, and harvest index (\%). Grain yield/feddan was calculated based on plot yield. Percentage of total protein in grains was measured by Near Infrared Analyzer according Granland and Zimmerman (1975). All the data collected on wheat or associated weeds were statistically analyzed according to Snedecor and Cochran(1980) and the means were compared at 0.05 level of significance using the LSD test in each season of this study.

\section{RESULTS AND DISCUSSION}

A. Weeds:

\section{Effect of tillage systems:}

As shown in Table (1) tillage systems had no significant effect on fresh and dry weight of annual weeds in the two seasons, though $\mathrm{T}_{2}$ (normal tillage and false irrigation) resulted in lighter weed weights than $T_{1}$. This may be attributed to the stimulating effect of the false irrigation. Fresh and dry weights associated with $T_{2}$ were reduced by 6.3 and $6.7 \%$ and by 6.3 and $3 \%$

Fayoum J. Agric. Res. \& Dev., Vol.23, No.1,(B). January, 2009 
in the first and second season respectively, as compared to those of $T_{1}$ treatment. In this concern, Wicks et al (1994) reported that weed species not previously observed have rapidly appeared in fields following elimination of preplanting tillage. Buhler et al (1995) indicated that tillage systems greatly affect weed seed production and management. However, Mishra et al (2005) obtained the highest grain yield (4.76 t/fed.) from zero tillage.

\section{Effect of sowing methods:}

Wheat sowing methods had significant effect on the associated weeds in both seasons (Tables 1). Drilling method decreased the fresh weight of weeds by 20.4 and $23.8 \%$ and dry weight by 19.4 and $17.2 \%$ in the first and second season, respectively, as compared with broadcasting method. This means that the systematic arrangement of wheat plants in drilling method may be reduced the chance and hampered weed growth. These results are in agreement with those of Mishra and Tiwari (1999), Abd El-Samie (2001), Yadav et al (2001) and Galal (2003) who revealed that drilling method surpassed broadcasting one in depressing weed growth and decreasing their fresh and dry weights and improving wheat grain yield.

\section{Effect of weed control treatments:}

Fresh and dry weights of weeds were significantly affected by weed control treatments (Tables 1). Tribenuron-methyl herbicide (WC1)was the most effective treatment against the broad leaved fresh weight causing reduction of 93.4 and $96.4 \%$ and dry weight causing reduction of 93.5 and $96.1 \%$ in the first and second season, respectively. It is weed known that Tribenuron-methyl herbicide inhibits acetolactate synthase enzyme (ALS) in the dictoyledonous plants and some grasses and consequently retard biothynthesis of many essential amino acids in these weeds. $\operatorname{Ray}(\mathbf{1 9 8 4})$ confirmed that Sulfonylurea herbicides inhibit ALS enzymes and decreased biosynthesis of leuceine, isolucine and valine. Inhabitation of amino acids synthesis was happened within 6 hours of application (Zimdahl, 1993). The obtained results are in line with those reported by Abd El-Samie (2001) and Sinha and Singh (2004) who applied similar herbicides and reached similar conclusion. The data showed also that hand weeding caused reduction of 60.8 and $78.8 \%$ of fresh broad leaved weeds, and of 61.6 and $74.8 \%$ of dry weight in the first and second season, respectively, compared with the unweeded check. These results are in harmony with those obtained by El-Kholi and Metwally (2001), Abd El-Halim (2004) and Sujoy et al (2006). All the first and the second order interactions among the experimental factors did not reach the level of significance in both seasons.

\section{B. Wheat growth parameters:}

\section{Plant height $(\mathbf{c m})$ :}

$\mathrm{T}_{2}$ treatment produced significantly taller plants than those of $\mathrm{T}_{1}$ treatment due to the desirable effect of false irrigation (Table2). The accounted increases in plant height of $\mathrm{T}_{2}$ over $\mathrm{T}_{1}$ were 1.9 and $2.7 \%$ in the first and second season, respectively. These results support those of Tunio et al (2004). Drilling method significantly increased the plant height of wheat by $3.3 \%$ over that of broadcasting method. Galal (2003) found similar results. All manual and chemical weed control treatments gave significantly taller plants than those of unweeded one in favourable to Tribenuron-methyl followed by Isogard $\left(\mathrm{WC}_{2}\right)$ and then hand weeding $\left(\mathrm{WC}_{3}\right)$ in the two seasons.

Fayoum J. Agric. Res. \& Dev., Vol.23, No.1,(B). January, 2009 
Table 1

Fayoum J. Agric. Res. \& Dev., Vol.23, No.1,(B). January, 2009 
Table 2

Fayoum J. Agric. Res. \& Dev., Vol.23, No.1,(B). January, 2009 
The superiority of wheat growth with these three treatments may be reflected their relative reduction effect of broad leaved weeds. These results are in general agreement with those obtained by Abd El-Samie (2001) and Pandey and Kumar (2005).

2. Number of tillers/plant:

Data in Table (2) reveal that number of tillers/plant was significantly influenced by weed control treatments, but not affected by tillage system and sowing methods.

The application of Tribenuron-methyl (WC1) increased number of tillers/plant by 26.1 and $37.6 \%$ in the first and second season, respectively, compared to the unweeded treatment. Hand weeding and Isoproturon treatments showed the same trend. This mean that the presence of weeds caused reduction in tillering capacity of wheat plants. Weed infestation reduced light intensity available for wheat plants and consequently decreased photosynthesis activity of shaded plants. Mitchell and Close (1955) suggested that number of tillers in shaded plants was determined by the amount of light energy available for photosynthesis to the plant as a whole and not by light intensity at the base. Mitchell (1979) reported that tillering was strongly influenced by plant competition and light intensity.

Significant effect of interaction between sowing methods and weed control treatments on tillering was detected where the highest values (6.61 and 7.16 tiller) were obtained from broadcasting $\left(\mathrm{SM}_{2}\right)$ interacted with application of Tribenuron-methyl, while the lowest values (4.48 and 4.66 tiller) were obtained from broadcasting interacted with unweeded check $\left(\mathrm{WC}_{4}\right)$ in the first and second season, respectively.

\section{Number of spikes/plant:}

As shown in Table (3) tillage system and sowing methods had no significant effect on number of spikes/plant in the two seasons, but weed control treatment significantly affected the trait (Table 3 ). Tribenuron-methyl treatment $\left(\mathrm{WC}_{1}\right)$ produced the highest number of spikes/plant that increased those of unweeded check by 31.8 and $45.8 \%$ in the first and second season, respectively. Significant differences in number of spikes due to the interaction between sowing method and weed control treatment was recorded. The highest values (5.95 and 6.83 spike) resulted from broadcasting $\left(\mathrm{SM}_{2}\right)$ with $\mathrm{WC}_{1}$ interaction, whereas the lowest values (3.9 and 4.08 spike) resulted from $\mathrm{SM}_{2} \times \mathrm{WC}_{4}$, were observed in the first and second season, respectively.

\section{Flag leaf area $\left(\mathrm{cm}^{2}\right)$ :}

Data in Table (3) show that tillage systems had no significant effect of flag leaf area. But the trait was significantly affected by sowing methods in the second season in favour to drilling method that surpassed broadcasting one by $7.3 \%$. Also, the trait was significantly influenced by weed control treatments in both seasons, where the highest values were recorded in plots treated with Isoproturon $\left(\mathrm{WC}_{2}\right)$ and Tribenuron-methyl $\left(\mathrm{WC}_{1}\right)$ in first and second season respectively. These results are in line with those of Gaweesh, Salwa et al (1992) who reported superiority of chemical over manual weed control treatments. The interaction between tillage systems and weed control treatments was of significant effect on flag leaf area in the second season.

Fayoum J. Agric. Res. \& Dev., Vol.23, No.1,(B). January, 2009 
Table 3

Fayoum J. Agric. Res. \& Dev., Vol.23, No.1,(B). January, 2009 
The highest value $\left(25.26 \mathrm{~cm}^{2}\right)$ was obtained from $\mathrm{T}_{2} \times \mathrm{WC}_{2}$ interaction, while the lowest value $\left(21.26 \mathrm{~cm}^{2}\right)$ was obtained from $\mathrm{T}_{2} \times \mathrm{WC}_{4}$ interaction.

\section{Seed yield and yield components:}

\section{Plant height (cm):}

Plant height exhibited insignificant differences due to tillage systems, but it was significantly influenced by sowing methods in the first season (Table 4). Drilling method increased plant height by about $2 \%$ over that of broadcasting one. These results are in accordance with those of Abd ElSamie (2001) and Galal (2003). The trait was also significantly influenced by all three chemical and manual weed control treatments which produced taller plant than those of unweedy check. Compared with the unweedy check, Tribenuron-methyl $\left(\mathrm{WC}_{1}\right)$ gave the highest increase $(11 \%)$ followed by Isoproturon $\left(\mathrm{WC}_{2}\right)$ and hand weeding, $\mathrm{WC}_{3}(8 \%$ for both) in the first season. The corresponding increases in the second season were 7.4, 8.5 and 4.5\%, respectively. These findings confirmed those obtained by Abd El-Samie (2001) and Sinha and Singh(2004) who suggested that weed control treatments resulted in taller plants and better growth than those of unweedy one.

Significant differences in plant height due to the interaction between tillage systems and weed control treatments in the second season. The highest value $(112.55 \mathrm{~cm})$ was obtained from $\mathrm{T}_{2} \times \mathrm{WC}_{2}$ interaction, while the lowest value $(100.85 \mathrm{~cm})$ was produced by $\mathrm{T}_{2} \times \mathrm{WC}_{4}$ interaction.

Table 4. Plant height $(\mathrm{cm})$ of wheat at harvest as affected by tillage systems, sowing methods and weed control during 2006//2007and 2007/2008 seasons.

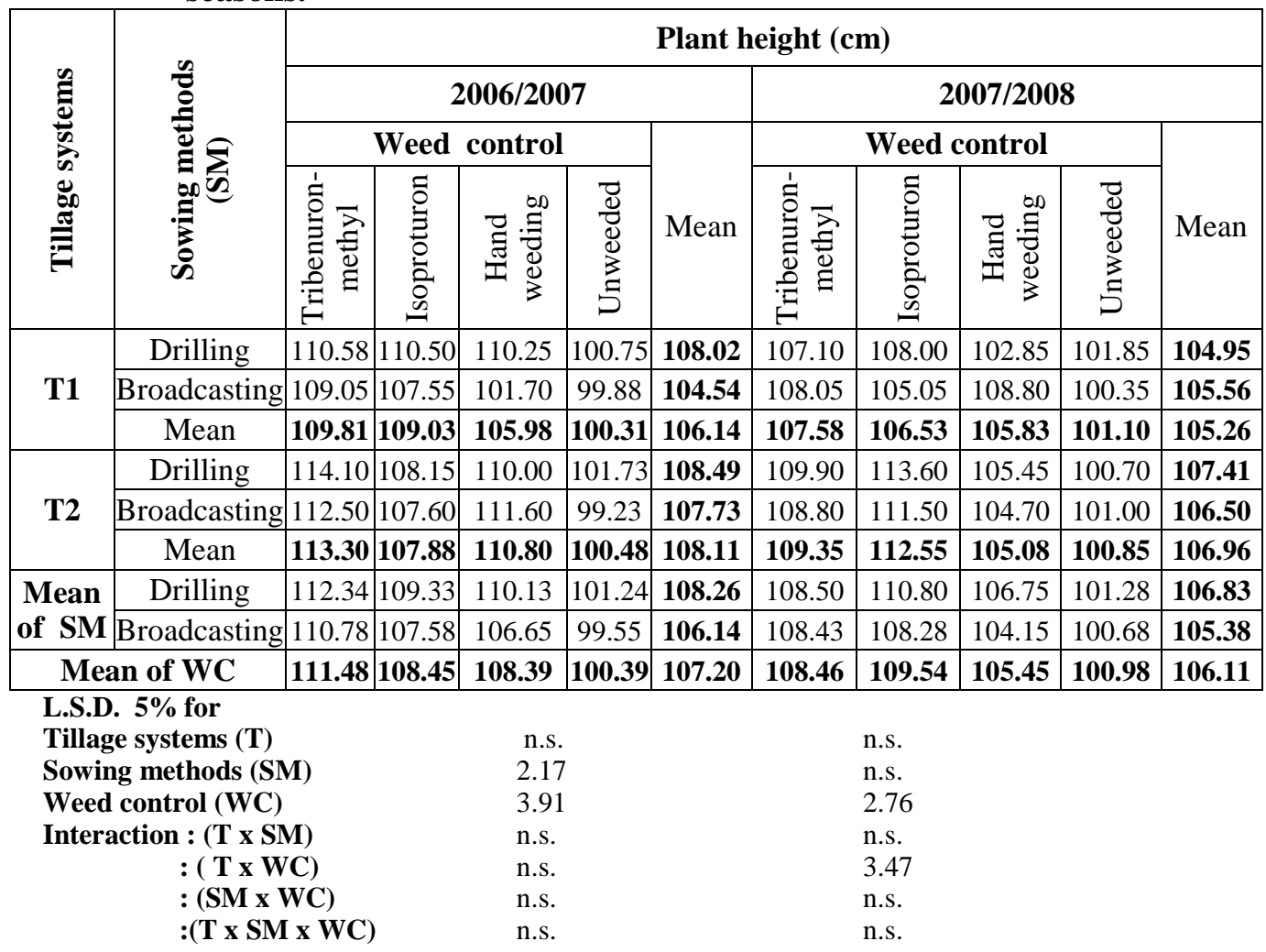

Fayoum J. Agric. Res. \& Dev., Vol.23, No.1,(B). January, 2009 


\section{Number of spikes $/ \mathrm{m}^{2}$ :}

Tillage systems had significant effect on number of spikes $/ \mathrm{m}^{2}$, where $\mathrm{T}_{2}$ produced higher number (344.1) than that of $\mathrm{T}_{1}$ (309.2 spike) in the second season. Whereas, the trait was insignificantly affected by sowing methods (Fig.1). The mechanical and chemical weed control treatments surpassed unweeded one (Fig.1). Similar results were previously obtained by Abd ElSamie (2001), Tunio et al (2004) and Nadeem et al (2007). Interference with growth of wheat is not definite only in the competition impact, but mostly include also the allelochemical exudates by weeds in soil and their harmful effect on germination, growth and productivity of wheat (Fayed et al, 2003). Similar results on the harmful effect of weeds on growth of wheat plants were reported by Abd El-Samie (2001) and Jose et al (2008).

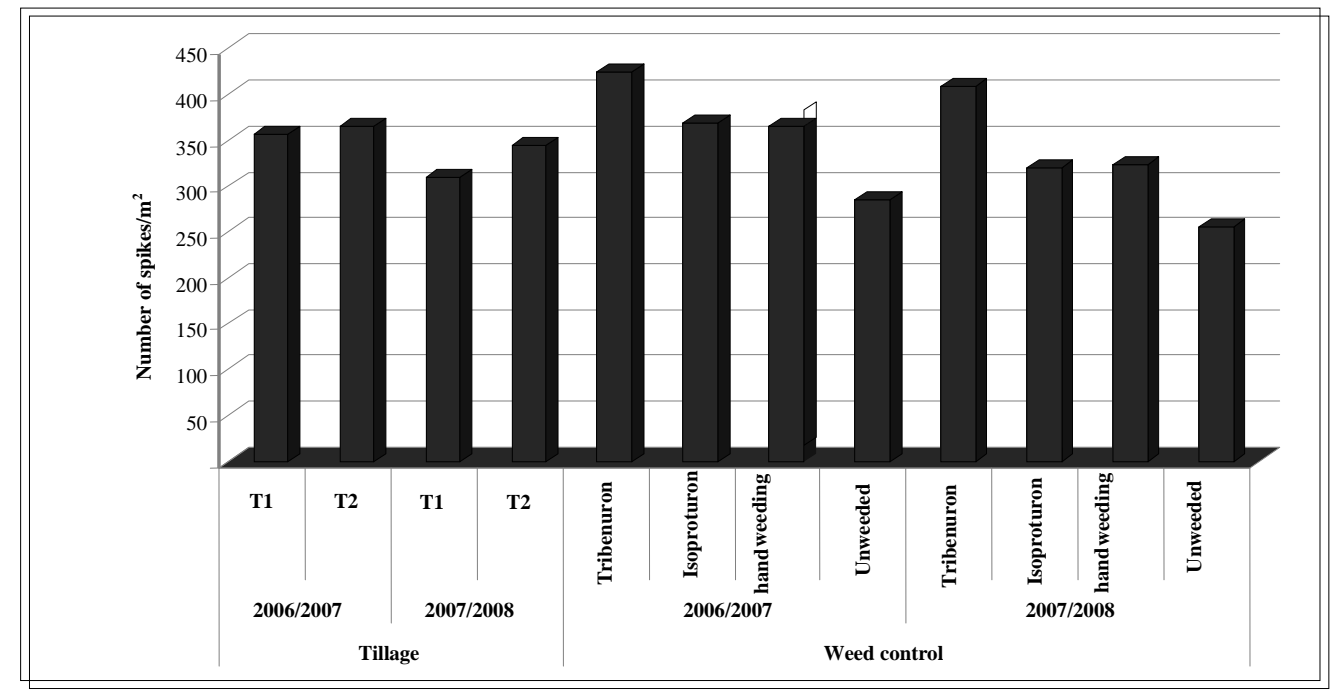

Fig.1. Number of spikes $/ \mathrm{m}^{2}$ of wheat at harvest as affected by tillage systems, sowing methods and weed control treatments during 2006/2007 and 2007/2008 seasons.

\section{Number of grains/spike}

The two tillage systems $T_{1}$ and $T_{2}$ had significant effect on the trait (Table 5) in the first season producing 48.63 and 51.88 grains/spike, respictively. for the two systems. However, the trait did not significantly affect by sowing methods (SM). Compared with unweeded treatment, all mechanical and chemical weed control ones were superior in favour to Tribenuron-methyl $\left(\mathrm{WC}_{1}\right)$ which increased grains/spike by 25.4 and $18.6 \%$ in two seasons, respectively. The data confirmed the detrimental effect of weed infestation on number of grains/spike. Weeds in unweeded treatment reduced number of grains/spike compared to those of hand weeding and Isoproturon treatments by 11.1 and $8.9 \%$ in the first season and by 9.5 and $7.9 \%$ in the second one, respectively. SM x WC interaction had significant effect on grains/spike where the highest (57.95) and the lowest (41.18) were obtained from $\left(\mathrm{SM}_{2} \times \mathrm{WC}_{1}\right)$ and $\left(\mathrm{SM}_{2} \times \mathrm{WC}_{4}\right)$ interactions respectively. The obtained

Fayoum J. Agric. Res. \& Dev., Vol.23, No.1,(B). January, 2009 
Table 5

Fayoum J. Agric. Res. \& Dev., Vol.23, No.1,(B). January, 2009 
results may be due to the enhanced growth, number of fertile flowers and the utilization of edaphic and above ground environmental factors to form high number of grains. These results are in full agreement with those reported by Tessema and Tanner (1997), Abd El-Samie (2001) and El-Bawab and Kholousy (2003).

\section{Grains weight/spike:}

As shown in Table 5, tillage systems showed significant effect on grains weight/spike in the first season, where $\mathrm{T}_{1}$ recorded higher weight $(2.49 \mathrm{~g})$ than that of $\mathrm{T}_{2}(2.29 \mathrm{~g})$. Drilling method $\left(\mathrm{SM}_{1}\right)$ significantly increased grain weight/spike by 6.03 and $2.8 \%$ over that of $\mathrm{SM}_{2}$ in the first and second season, respectively. Compared with unweedy, the weed control treatments increased grain weight/spike in favour to $\mathrm{WC}_{1}$ treatment which exceeded unweedy one by 28.8 and $22.0 \%$ in first and second season, respectively. The superiority of wheat growth with $\mathrm{WC}_{1}$ treatment may be attributed to its effective reduction of weeds associated with wheat plants. These results surpassed unweeded check confirming the results reported by several authors (Fayed et al, 1998; and Galal, 2003). All interactions had no significant effect on the trait indicating that the studied factors were independent action (El-Naggar, 1996 and Shahida et al, 2005).

\section{Seed index $(\mathrm{g})$ :}

The trait did not affected by tillage systems, but it significantly influenced by sowing methods in the second season (Table 6). Drilling method had higher seed index $(49.32 \mathrm{~g})$ than broadcasting one $(48.55 \mathrm{~g})$. The trait was also significantly affected by weed control treatments in favour to Tribenuron-methyl $\left(\mathrm{WC}_{1}\right)$ that produced the highest values exceeded those of unweeded check by 6.18 and $8.9 \%$ in the first and second season, respectively. Tillage systems and sowing methods combined with effective weed control treatment favored growth potential of wheat plant and consequently increased their photosynthesis capacity. Accordingly, amounts of metabolites synthesis by crop plant were increased and enhanced their translocation and accumulation in developing grains to increase seed index of wheat plant (Tessema and Tanner, 1997).

\section{Grain yield (t/fed.):}

Tillage systems had significant effect of grain yield, where $T_{2}$ gave the highest yields (2.16 and 2.12t) compared with those of $\mathrm{T}_{1}(2.04$ and 1.86t) in the first and second season, respectively (Fig.2). Sowing methods had also significant effect on trait in the second season, where drilling method (2.11t) outyielded the broadcasting one (1.87t) in grain yield. These results are in line with those obtained by Mishra and Tiwari (1999); Abd El-Samie (2001) and Galal (2003). All manual and chemical weed control treatments caused significant increases in grain yield over the unweeded one. The highest yield was produced from Tribenuron-methyl ( $\left.\mathrm{WC}_{1}\right)$ treatment (Fig.2).

Fayoum J. Agric. Res. \& Dev., Vol.23, No.1,(B). January, 2009 
Table 6. Seed index of wheat at harvest as affected by by tillage systems, sowing methods and weed control treatments during 2006/2007 and 2007/2008 seasons.

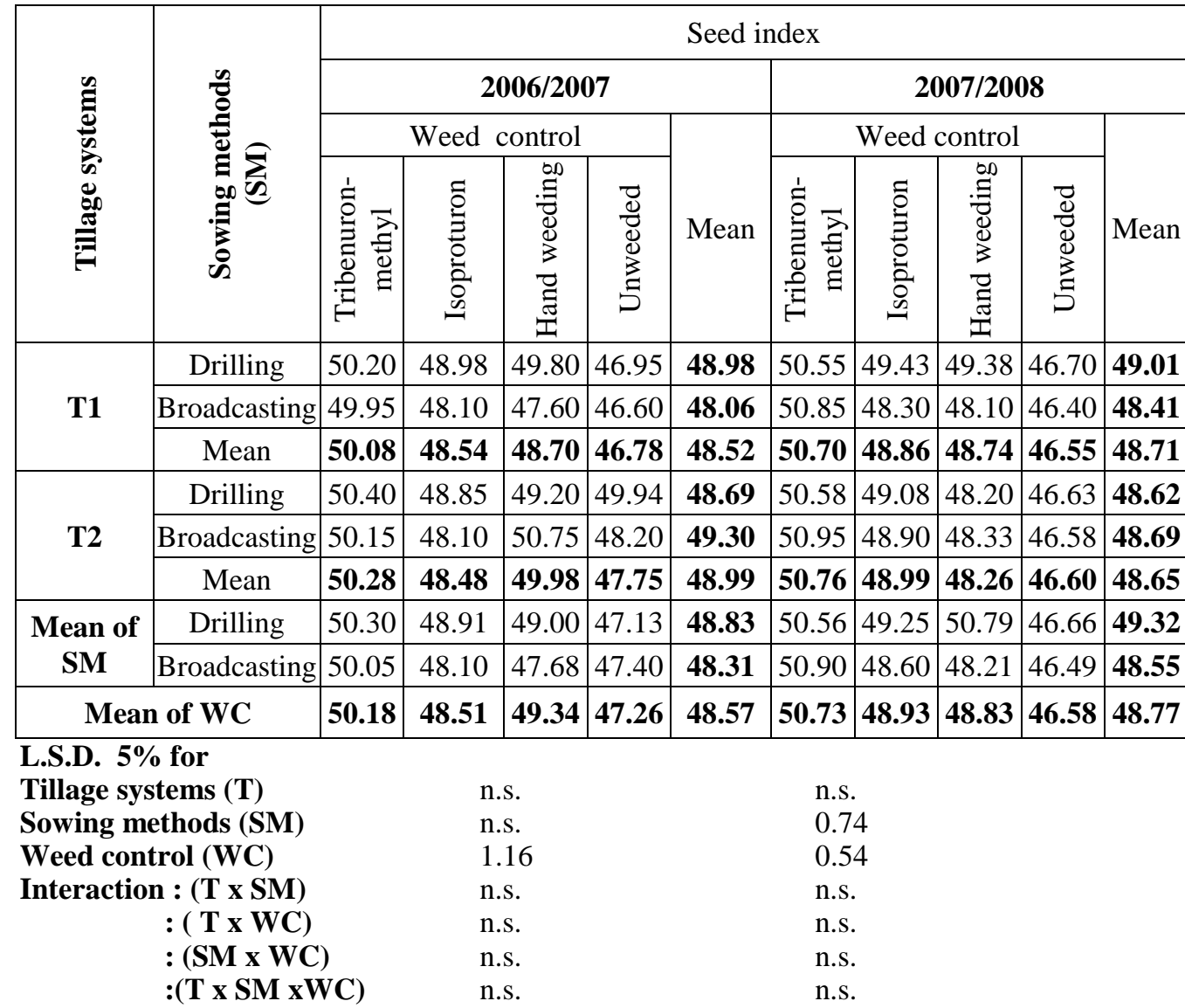

Sharp reduction in grain yield of unweeded check reflected heavy weed competition against wheat plants along growing season, weeds impede the growth and yield of crop in relation to the event of weed invasion. Herein, crop plant is often unable to satisfy its optimum demand for light, water, nutrients and space. In addition, the hazardous impact of weeds is not definite only in the competition effect but mostly include also allelochemical exudates by weeds in the soil and ther harmful effect on establishment, growth and yield of the crop plant (Fayed et al, 2003). Effective weed control treatments minimized below and above ground competition which wheat plants suffered and consequently furnished suitable environmental factors to crop plants to grow well and reflected in noticeable increases in vegetative growth. Eradication of weeds will be increased the amount of light intercepted by wheat plants and accounts for the increase in the amount of metabolites synthesized by crop plants. This also increased the proportion of assimilates migrated to spikes and grains and consequantly resulted in improved grain yield. similar results on the determental impact of weeds on wheat productivity were reported by Alam et al (1994); Abd El-Samie (2001); El-Bawab and Kholousy(2003); Galal(2003) Pandey and Kumar (2005) and Jose et al (2008).

Fayoum J. Agric. Res. \& Dev., Vol.23, No.1,(B). January, 2009 


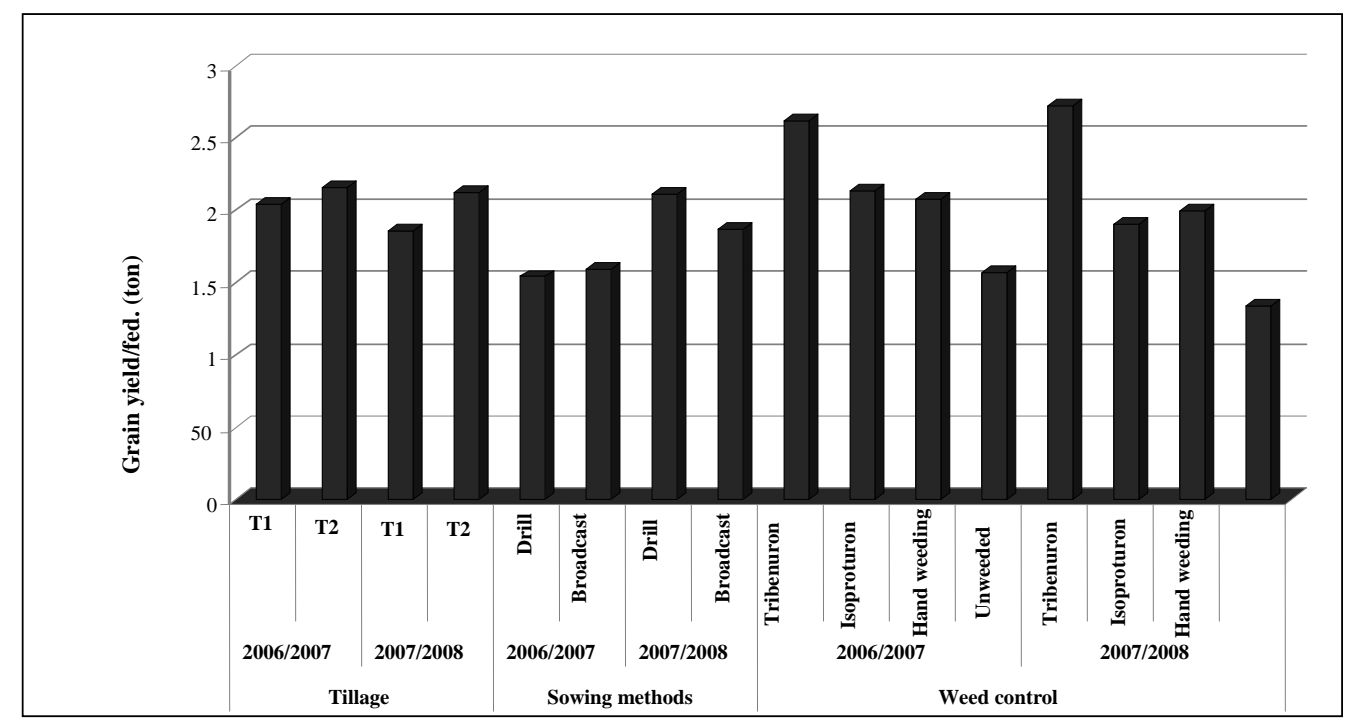

Fig 2.Grain yield/fed (ton) of wheat at harvest as affected by tillage systems, sowing methods and weed control treatments during $2006 / 2007$ and $2007 / 2008$ seasons.

\section{Straw yield (t/fed):}

Straw yield was significantly affected by tillage systems in the second season, where the highest value was gained by $\mathrm{T}_{2}$ which increased straw yield by $5.7 \%$ over that of $\mathrm{T}_{1}$ application. Similar results were previously reported by Sharma et al (2004) and Ozpinar (2006) who found marked effect of different tillage systems used by them on the straw yield.

The effect of sowing method on the trait was pronounced in the first season in favour broadcasting method which increased straw yield by $8.6 \%$ over that of drilling one (Table 7). Abd El-Samie (2001) recorded similar results. Weed control treatments were of significant effect on straw yield in both seasons. $\mathrm{CW}_{1}$ was the most effective treatment secured the highest straw yield, i.e., 3.79 and $4.32 \mathrm{t} / \mathrm{fed}$ in the first and second season, respectively, followed by $\mathrm{CW}_{3}$ and $\mathrm{CW}_{2}$, whereas the lowest straw yield was obtained from unweeded check. The later case may be explained that weeds left to interfere with wheat plants during the entire season significantly reduced straw yield as a result of decreasing of plant height and number of tillers/plant as mentioned above. These results are in accorelance of those reported by Abd El-Samie (2001) and Jose et al (2008).

\section{Harvest index $(\%)$ :}

As shown in Table (7) the trait did not significantly affect by tillage systems, while it showed marked effect by sowing method in the first season only. Drilling method $\left(\mathrm{SM}_{1}\right)$ increased harvest index by $11.3 \%$ over that of broadcasting one $\left(\mathrm{SM}_{2}\right)$. The trait was also influenced by weed control treatments. Tribenuron-methyl $\left(\mathrm{WC}_{1}\right)$ produced the highest value of harvest index, i.e. 0.72 and 0.63 , while unweeded check $\left(\mathrm{WC}_{4}\right)$ gave the lowest values, i.e. 0.59 and $0.41 \%$ in the first and second season, respectively. Tillage systems $\mathrm{x}$ weed control treatments interaction was of significant

Fayoum J. Agric. Res. \& Dev., Vol.23, No.1,(B). January, 2009 
effect on harvest index. the highest values $(0.77$ and $0.64 \%)$ were resulted from $\mathrm{T}_{2} \times \mathrm{WC}_{1}$ interaction in the first season andT $\mathrm{T}_{2} \mathrm{WC}_{3}$ in the second one,

Table 7

Fayoum J. Agric. Res. \& Dev., Vol.23, No.1,(B). January, 2009 
while the lowest values $(0.56$ and $0.39 \%)$ were obtained from $\mathrm{T}_{2} \times \mathrm{WC}_{4}$ interaction, in both seasons .

\section{Total protein $(\%)$ :}

Tillage system had marked effect on protein percentage in wheat grains in the first season, in favour to $\mathrm{T}_{2}$ treatment, (Fig 3). Sowing methods had also significant effect on protein percentage, where drilling method had higher protein percentage than those of broadcasting one, in the two seasons. Moreover, the trait was markedly affected by weed control treatments. Compared with unweeded Tribenuron-methyl $\left(\mathrm{WC}_{1}\right)$ recorded the highest values followed by Isoproturon $\left(\mathrm{WC}_{2}\right)$ and hand weeding $\left(\mathrm{WC}_{3}\right)$. Whereas the lowest percentage were produced from unweeded check, in the two respective seasons. Depending on the above mentioned results on weeds, wheat grow and yield, it is clear that effective elimination of weeds increased wheat growth parameters and improved its yield components. Such impact is mostly accompanied with a large active root system. Hence nutrients (particular $\mathrm{N}$ ) uptake increased and favoured synthesis of amino acids and accumulation of protein in wheat grains. Similar results were obtained by Cosser et al (1996) and Rahman et al (2001).

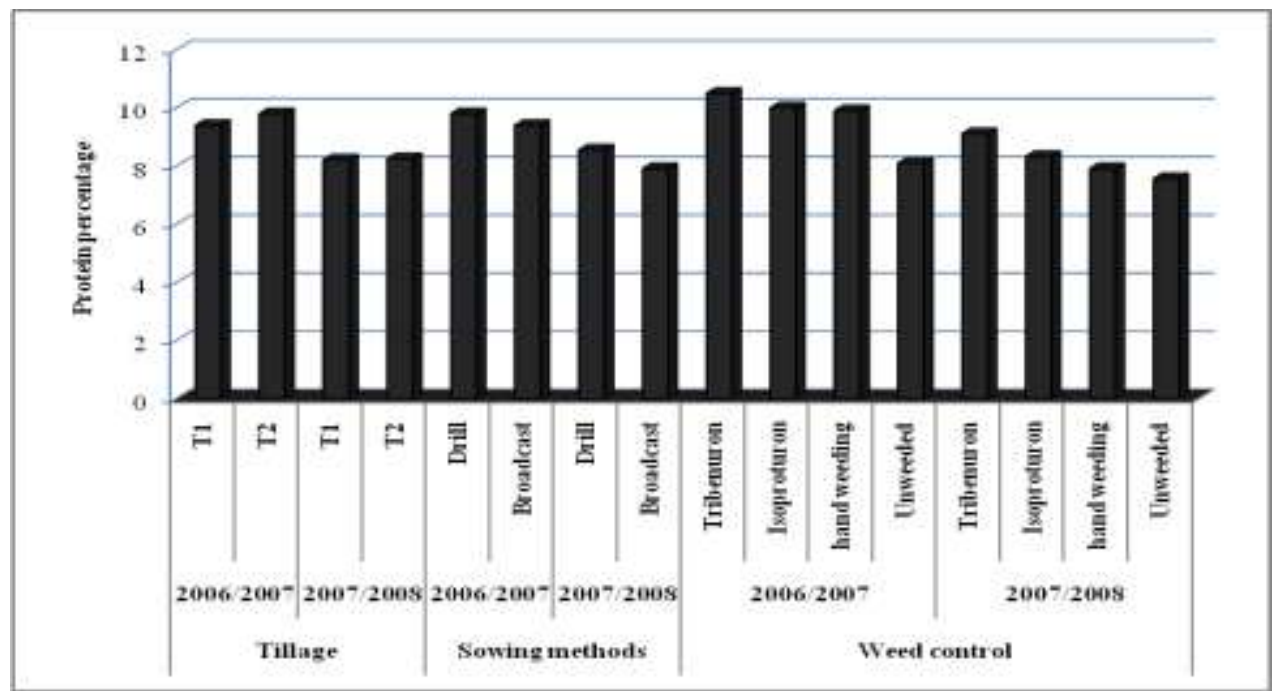

Fig (3): Total protein percentage of wheat as affected by tillage systems ,sowing methods and weed control treatment during 2006/2007 and 2007/2008 seasons.

Fayoum J. Agric. Res. \& Dev., Vol.23, No.1,(B). January, 2009 


\section{REFERENCES}

Abd El- Halim, S.H., 2004. Study the performance of herbigation technique through new irrigation systems in wheat with relation to herbicide efficiency and wheat growth. Ph.D. Thesis, Fac. of Agric. Ain Shams Univ., Egypt.

Abd El-Samie, F.S., 2001. Integrated weed management in wheat. Menofiya J. of Agric. Res., 26 (3): 619-633.

Alam, M.T.; M.A. Gaffer and M.A. Kashem, 1994. Critical period of weed competition in wheat (Triticum aestivum) as influenced by different seed rates . Indus. Res., 29(2):63-70.

Bhat, M.A. and S.S. Mahal, 2006. Performance of wheat (Triticum aestivum L.) genotypes under different planting and weed control methods. Crop Res. Hisar., 32(2): 153-156

Buhler, D.D.; J.L. Gunsolus; and D.F. Ralston, 1995. Effect of preplant tillage and planting on weed populations and mechanical weed control in soybean. Weed . Sci., 44:373-379.

Cosser, N.D.; M.J. Gooding; W.P. Davies and R.J. Froud-Williams, 1996. Effects of wheat dwarfing genes on grain yield and the quality of wheat in competition with Alopecurus myosuroides. $2^{\text {nd }}$ Int. Weed control Conf., Copenhagen. Depart. of Weed control and Pesticide Ecology:1089-1094.

El-Bawab, A.M.O. and A.O. Kholousy, 2003. Effect of seeding rate and method of weed control on the productivity of giza 2000 a promising barley line, under new land conditions. Egypt J. of Agric. Res., 81 (3): 1085-1097.

El-Kholi, H.M.A and G.M. Metwally, 2001. The indirect effect of some weed control treatments on wheat grain yield and some soil physical properties. Bulletin of the National Research Centre, Cairo, 26(3): 357-370.

El-Naggar, H.M.M., 1996. Response of wheat and associated weeds to some weed control treatments and sowing methods .Annals of Agric. Sci., Moshtohor. 34(3): 935-950.

Fayed, T.B; S.R.S. Sabry and S.H Aboul-Ela, 1998. Effect of wild oat (Avena fatua) herbicides on weed density, wheat grain yield, and yield components. Annals of Agric. Sci., Cairo, 43(1): 173-188.

Fayed, M.T.; A.A. Abd El-Gawad ; I.H. El- Geddawy and A.M. Abd ElAal, 2003. Relationship between weed density and sugar beet yield and quality. Proc. $10^{\text {th }}$ Conf. of Agron. Suez Canal Univ., Fac. Environ. Agric. Sci. El-Arish, Egypt. Soc. Agron.

Galal, A.H., 2003. Response of wheat and its associated weeds to sowing methods, seeding rates and weed control treatments. Assiut J. Agric. Sci., 34(5): 77-98.

Gaweesh, Salwa, S.M.; Fatma, E.E. El-Quesn and Sonaa. H. El- Gayar, 1992. Effect of foliar application with Bromoxynil, Micronutrients and Gibberellic acid on associated weeds, growth, yield and chemical composition of wheat. Bull. Fac. of Agric., Univ. of Cairo., 43, (3):895-916.

Fayoum J. Agric. Res. \& Dev., Vol.23, No.1,(B). January, 2009 
Granland, M. and D.C. Zimmerman, 1975. Oil content of sunflower seed as determined by wide line nuclear magnetic resonance. Acad. Sci., 27:123-133.

Jose, F.C.B.; B. Gottlieb and M. Carvalho, 2008. Effect of reduced doses of a post-emergence herbicide to control grass and broad-leaved weeds in no-till wheat under Mediterranean conditions. Crop Protection., $27: 1031-1037$.

Kassahun, Z. and R. Suwanketnikom, 2005. Relative influence of tillage, fertilizer, and weed management on weed associations in wheat cropping systems of Ethiopian highlands. Kasetsart J. Natural Sci.; 39(4): 569-580.

Kushwaha, B.L. and P.K. Singh, 2000. Comparative efficiency and economics of mechanical and chemical weed control in wheat. Annals of Plant Prot. Sci., 8(1): 71-75.

Madeira, J.; M.F. Dordio; R.S. Mira and C.L. Opes, 1984. Population level and concurrence of wild oat (Avena sterilis) in wheat field in portugal. Pro. of the EWRS $3^{\text {rd }}$ Symp. on weed problems in the Mediterranean area 2:461-468.

Marwat, K.B.; Z. Hussain; M. Saeed; Bakhtiar-Gul and S. Noor, 2005. Chemical weed management in wheat at higher altitudes. Pakistan J. of Weed Sci. Res., 11(3/4): 103-108.

Mishra, A.K. and R.C. Tiwari, 1999. Effect of seeding method and fertilizer application on weed biomass and yield of wheat (Triticum aestivum). Indian J. of Agron., 44(2): 353-356.

Mishra, J.S.; V.P. Singh and N.T. Yaduraju. 2005. Effect of tillage and weed control methods on weeds and wheat (Triticum aestivum) in vertisols. Indian J. of Weed Sci., 37(1/2): 96-97.

Mitchell, K.J., 1979. Crop growth and culture. Low State Univ. Press $6^{\text {th }}$ printing.

Mitchell, K.J. and S.T.J. Cloes, 1955. Effect of defoliation and shading on short-rotation ryegrass. New Zealand J. Sci. Tech. 36 :586-604.

Nadeem, M.A; A. Ali and A. Tanveer, 2007. Effect of different weed control practices and fertilizer levels on the weeds. Pakistan J. of Botany, 39(1): 173-182.

Oad, F.C.; M.H. Siddiqui and U.A. Buriro, 2007. Growth and yield losses in wheat due to different weed densities. Asian J. of Plant Sci., 6(1): 173-176.

Ozpinar, S., 2006. Effects of tillage systems on weed population and economics for winter wheat production under the Mediterranean dry land conditions. Soil and Tillage. Res., 87(1): 1-8.

Pandey, I.B. and K. Kumar, 2005. Response of wheat (Triticum aestivum) to seeding methods and weed management. Indian J. of Agron., 50(1): 48-51.

Pandey, A.P.; N.K. Singh; B.L. Singh and S.K. Tiwari, 2006 .Combined influence of tillage and herbicide application on weed dynamics and yield of wheat under rice - wheat system. J. of Living. World. 13(2): 26-29.

Fayoum J. Agric. Res. \& Dev., Vol.23, No.1,(B). January, 2009 
Prasad, .S.; Y. Singh; R.P. Singh and G. Singh, 2005. Effect of crop establishment, weed control method and time of nitrogen application on late sown wheat. Indian J. of Weed Sci., 37(1/2): 93-95.

Raghuvir, S.; S.S. Tomar and A. Kumar, 2006. Integrated weed management in wheat. Crop Res. Hisar., 32(3): 289-293.

Rahman, M.S.; A.M. Saker; M.S. Islam and N.K. Paul, 2001. Effect of soil moisture on grain yield of wheat (Triticum asstivum, L) cultivars. Environ. and Ecol., 19(2) : 304-308.

Ray, T.B., 1984. Site of action of chlorsulfuron. Inhibition of valine and isoleucine biosynthesis in plant .Plant Phys.75:827-831.

Richards, R.A., 1983. Manipulation of leaf area and its effect on grain yield in drought wheat. Assiut J. Agric. Res. 34:13.31.

Saini, J.P.; S.P. Attri; and N.N. Angiras, 1998. Integrated weed management in wheat + sarson intercropping system under mid-hill conditions of Himachal Pradesh. Indian J. Weed Sci., 30(1/2): 9-13.

Satao, R.N.; S.G. Padole and G.S. Lahariya, 1993. Integrated weed management in late sown wheat. Integrated weed management for sustainable agriculture. Proceedings of an Indian Society of Weed Science, International Symposium, Hisar. India., 10:20 November 1993. (3): 78-81.

Shahida, B.; K.B. Marwat; G. Hassan and B.A. Khan, 2005. Integrated weed management through herbicides and different seed rates in wheat. Pakistan J. of Weed Sci. Res., 11(3/4): 121-129.

Sharma, R.K.; K.S. Babu; R.S. Chhokar; and A.K. Sharma, 2004. Effect of tillage on termites, weed incidence and productivity of spring wheat in rice-wheat system of North Western Indian plains. CropProtection., 23(11): 1049-1054.

Singh, S.J.; K.K. Sinha; I.B. Pandey and S.S. Mishra, 2000. Cultural and chemical weed control in late sown wheat. J. of Res. Birsa Agric. Univ., 12(2): 249-251.

Sinha, K.K. and S.J. Singh, 2004. Efficacy of Isoprturon with and without surfactant on weed suppression in wheat (Triticum aestivum L). Indian J. Agron., 49(4): 254-257.

Snedecor, G.A. and A.D. Cochran, 1980. Statistical methods $7^{\text {th }}$ Edition, Iowa State Univ.

Sujoy, D.; A.K. Sarkar; S.P. Bhattacharya and A. Saha, 2006. Effect of various weed management practices in wheat. Environ. and Ecol., 24 (3): 620-622.

Tessema, T and D.G. Tanner, 1997. Grass weed competition and calculated economic threshold densities in bread wheat in Ethiopia. African crop Sci. j., 5(4): 371-384.

Tunio, S.D.; S.N. Kaka; A.D. Jarwar and M. R. Wagan, 2004. Effect of integrated weed management practices on wheat yield. Pakistan-J of Agric. Agric Engineering,-Veterinary Scie., 20(1): 5-10 .

Wicks, G.A., O.C. Burnside and W.L. Felton, 1994. Weed control in conservation tillage systems. In: Unger, P.W. (Ed.), Managing Agricultural Residues. Lewis Publishers, Boca Raton, FL, pp. 211244.

Fayoum J. Agric. Res. \& Dev., Vol.23, No.1,(B). January, 2009 
Yadav, D.P.; R.D. Vaishya and G. Singh, 2001. Response of late sown wheat to method of sowing, seed rate and weed management practices. Annals of Agric. Res ., 22(3): 429-431.

Zand, E.; M.A. Baghestani; S. Soufizadeh; R. Pour Aza; M. Veysi; N. Bagherani; A. Barjasteh, M. MKhayami and N. Nezamabadi, 2007. Broadleaved weed control in winter wheat (Triticum aestivum L.) with post-emergence herbicides in Iran .Crop-Protection. 26(5): 746-752.

Zimdahl, R.L , 1993. Fundamentals of Weed Science .Academic press. Inc. San Digo, Boston .

$$
\begin{aligned}
& \text { التأثير المشترك لنظم الخدمة وطرق الزراعة ومعاملات مقاومة الحشائش } \\
& \text { على محصول القمح والحشائش المصاحبة النقاتية }
\end{aligned}
$$

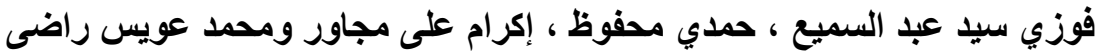

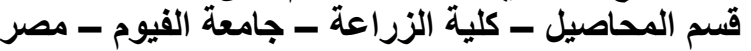

أقيمت تجربتـان حقليتـان بمحطـة التجـارب الزر اعيـة بكليـة الزر اعـة ـ جامعـة الفيوم خـلال

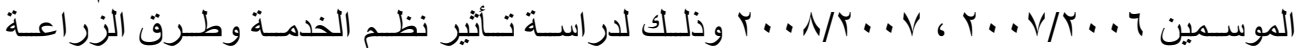

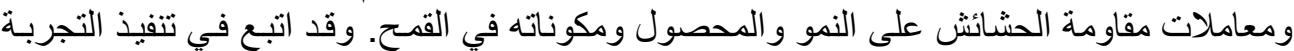

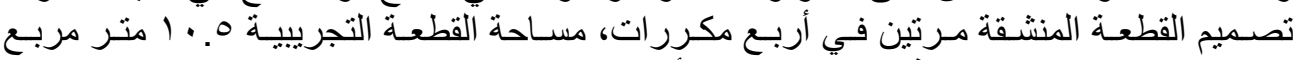
و استخدم الصنف سخا ؟ 9 وفيما يلي تلخيص لأهم النئ النتائج المتحصل عليها:

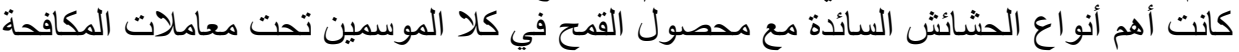

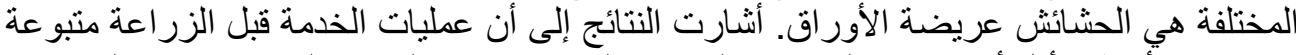

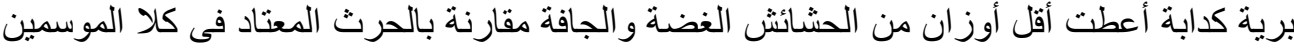

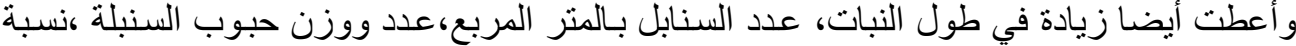

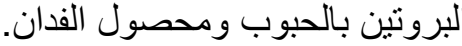

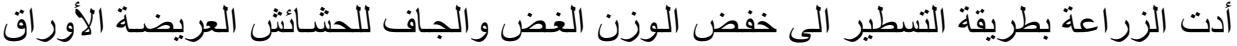

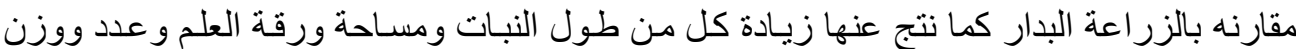

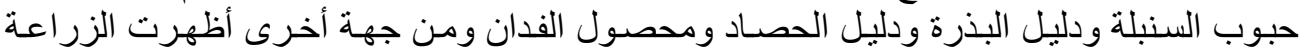

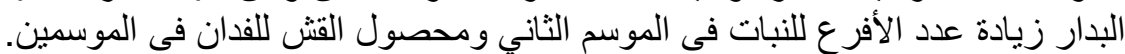

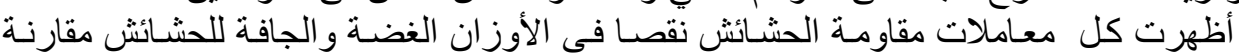

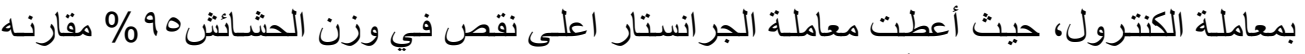

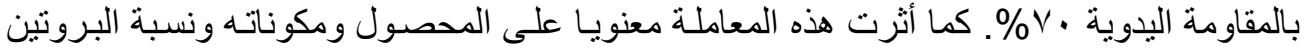

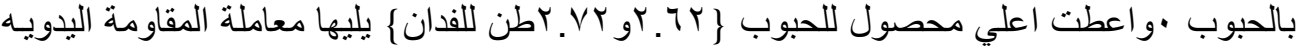

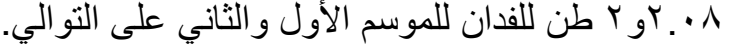

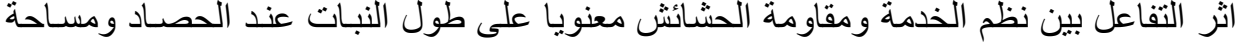

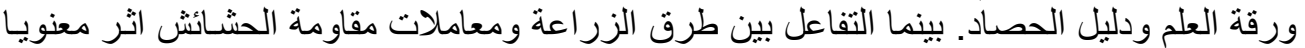
على عدد الأفرع و السنابل للنبات و عدد الحبوب بالسنبلة.

Fayoum J. Agric. Res. \& Dev., Vol.23, No.1,(B). January, 2009 